\title{
Essay
}

\section{Facebook - en pest over demokratiet}

\section{Dissidens: Det er op ad bakke at få en befolkning af informanter bevidstgjort om den politiske betydning af skellet mellem privat og offentligt.}

Af Klavs Birkholm *)

\section{1.}

Unge mennesker, der er født efter 1980, har stort set ingen levende erindring om Jerntæppet og Den Kolde Krig i Europa. Kommunismen er lykkeligvis forsvundet fra kontinentet, og det samme er den yngre generations hukommelse om denne brutale statsform. Man har måske set et par film fra DDR-tiden - De Andres Liv fra 2006 eller Barbara fra 2012. Måske har man læst Eugen Ruges fortræffelige slægtsroman fra 2011, I tider med aftagende lys. Det er jo ellers ikke, fordi der mangler litteratur og film fra Stalin-tidens terror i Rusland eller fra Polen, Ungarn og Tjekkoslovakiet under kommunismens åg; men hvis værkernes dramatiske tema er de totalitære magtmekanismer, hvilken relevans har så disse kulturhistoriske efterladenskaber i vor tid - ... hvis man altså ikke lige er historiker?

Enorm relevans! Det er, som om nutidens bærende generation med Murens Fald også har mistet den seismografiske fornemmelse for, når og hvor den personlige frihed kommer i fare. Der er ikke længere nogen radar, der slår alarm - en pointe, som også den bulgarske politolog Ivan Krastev gør opmærksom påi. Vi værdsatte demokratiet langt mere engageret, dengang vi kendte til alternativet.

Facebook-koncernens globale sejrsgang er det bedste eksempel. Som den tidligere officer i STASI (DDR's frygtede hemmelige politi), Wolfgang Schmidt sagde i 2013: "For os ville det have været en opfyldelse af vore hedeste drømme"ii. Han refererede til NSA's indsamling af informationer fra Facebook. Med hjælp fra mere eller mindre beredvillige DDR-borgere - kaldet informanter lykkedes det STASI at indsamle gennemsnitligt 173.081 stykker personoplysning om måneden. Til sammenligning indsamler Facebook nu 1.230.000.000 (1,23 milliarder) stykker personoplysning om måneden. Mere end 7 millioner gange så mange oplysninger dagligt. 
Og nej, det er ikke en helt anden slags personoplysninger! Bortset fra, at der er langt mere billedmateriale i Facebooks gogolantiske databank, er der ligesom i DDR-tiden tale om et katalog over den enkelte persons længsler og drømme, hans eller hendes seksuelle tilbøjeligheder, informationer om utroskab, om sort arbejde, om sympatier og antipatier, herunder politiske symog antipatier, om opsparing og forbrug - tilsat fotos af børn og børnebørn i hverdag og fest. For dissidenterne i DDR og i hele Centraleuropa var det en heroisk kamp op ad bakke at få befolkningen af informanter politisk bevidstgjort om, at den slags langt fra er harmløse informationer. "Herregud", sagde informanterne, "vi giver så lidt, og vi får så meget til gengæld". Sikkerhed for job og hvert tiende år en ferie ved Sortehavet, for eksempel.iii Til gengæld accepterede de, med Václav Havels ord, stiltiende at leve på en løgn. Det var det totalitæres diskrete magtmekanisme.

"Herregud", siger Facebooks halvanden milliard brugere tilsvarende, "vi giver så lidt, og vi får så meget til gengæld" Men hvor lidt? Og hvor meget?

2.

Overvågning er blevet den centrale forretningsmodel i den datadrevne økonomi, hævder flere af dens skarpeste analytikere, blandt andre Bruce Schneier og Shoshana Zuboff.iv (Det er i øvrigt et forhold, som nationaløkonomerne endnu ikke har opdaget.) Der har i den senere tid kunnet konstateres en voksende, offentlig opmærksomhed om dele af denne overvågning, og også mindre bevidste Facebook-brugere må vel efterhånden vide, at tjenesten ikke kan være gratis, uden at de selv leverer en eller anden form for modydelse, der kan monetiseres. Så spørgsmålet er: Hvorfor bidrager de mange millioner brugere alligevel frivilligt til denne forretningsmodel? Hvad motiverer dem til denne noget-for-noget?

Én mulig forklaring kan være, at flertallet anser privat spionage for langt mere ufarlig end statslig spionage. For de fleste af os er der utvivlsomt noget meget mere suspekt ved at blive hvirvlet ind i staternes sikkerhedsapparat, mens den private overvågning - det er vel en anden sag? Den foregår vel bare for at påvirke os til at købe det ene eller det andet på markedet?

En af demokratiets vigtigste grundpiller er vores skelnen mellem det offentlige og det private.v På baggrund af årtiers infotainment, reality-tv og de såkaldt sociale medier kan der derfor være noget betryggende ved, at mange borgere stadig fastholder et skel imellem, hvad der er statsligt, og hvad der er privat - eksempelvis statslige og privatejede data - men det er desværre ikke længere en skelnen, som magtsystemerne respekterer. Den nyliberalistiske revolution, der begyndte tidligt i 1980'erne og for alvor slog igennem efter kommunismens sammenbrud, satte en 
privatisering af de fleste offentlige tjenester på dagsordenen - og noget af det, der efterhånden er blevet privatiseret mest tilbundsgående, er netop efterretningstjenesterne. Vladimir Putin, Recep Erdogan og Viktor Orbán behøver ikke længere organisere store apparater til at indsamle data om dén og dén specifikke borger - det har de private virksomheder til at gøre. Det samme gælder naturligvis Donald Trump og en hvilken som helst kommende leder i et hvilket som helst europæisk land: Man køber sig til informationer. Eller opkræver dem slet og ret. Det kaldes outsourcing.

På markedet for data er Facebook Inc. den i særklasse største aktør. Koncernen sælger de informationer, som brugerne har tastet ind om sig selv og deres venner. Der er mange købere. Blandt de største er de (diskret arbejdende) globale "datamarketing" virksomheder som Alliance Data (årsindkomst \$7,14 milliarder), Axciom (\$1,15 milliarder) og LatentView Analytics $(+\$ 1$ milliarder). Disse virksomheder bryster sig alle med, at de kan give deres kunder - som måske sælger boliger, måske dametøj, måske hårde hvidevarer, måske naturmedicin - "et $360^{\circ}$ billede" af hver enkelt potentiel kunde. ${ }^{\text {vi }}$ Den ydelse kan datamarketing selskaberne ikke mindst tilbyde takket være den uudslukkelige kilde, som Facebook giver dem - en samhandel, der har gjort Facebook Inc. til én af verdens rigeste koncerner med en årlig indtjening omkring \$40 milliarder. (Og efterhånden har løftet stifter og ejer Mark Zuckerbergs personlige formue op over \$70 milliarder).

Måske er det selve størrelsen af disse tal, der danner baggrund for en helt anden mulig forklaring på, at Facebooks brugere accepterer at medvirke til en systematisk overvågning af ikke bare sig selv, men også hele deres vennekreds. Tre forskere fra Pennsylvania University konkluderede i 2015 efter en survey-undersøgelse af netop det spørgsmålvii, at et meget stort antal brugere i USA i realiteten har opgivet at beskytte deres data; de anser sig for magtesløse over for virksomhedernes bestræbelser på at kigge ind i selv deres inderste gemmer; derfor ræsonnerer mange, at så kan de lige så godt få en smule til gengæld. viii Med det ræsonnement er vi lige lukt tilbage ved "de magtesløses magt", som dissidenten Havel skrev så overbevisende om, inden han blev præsident.

\section{3.}

På markedet for personoplysninger har Facebook Inc. imidlertid mere at tilbyde end de indsamlede data om brugernes vaner og længsler. Hovedkvarteret på 1 Hacker Way i det nordøstlige Palo Alto er også verdens største adfærdspsykologiske laboratorium, der anvender virksomhedens 'brugere' som forsøgspersoner i jagten på endnu mere 'viden' om deres drømme og tilbøjeligheder. 
Lige nu består Facebooks data science team af 59 forskere. Som teamets tidligere leder (2007-13), Cameron Marlow har beskrevet deres situation:

"For første gang er vi i besiddelse af et mikroskop, der ikke blot gør det muligt for os at udforske social adfærd på et meget detaljeret niveau - et niveau vi aldrig tidligere har været i stand til at se - men også tillader os at udføre eksperimenter, som millioner af brugere udsættes for."ix Ét af de eksperimenter, som er lækket fra det ellers temmelig hemmelighedsfulde laboratorium, er et forsøg på af afdække, om følelser kan være smitsomme. The data science team opdelte en udvalgt kohorte på 689.000 (!) Facebook-brugere i to forsøgsgrupper - i den ene gruppe fjernede teamet alle negative ord og udtryk fra brugernes newsfeed, i den anden gruppe fjernede man alle de positive ord. Teamets konklusion var, at de budskaber ('poster'), som brugerne efterfølgende selv skrev, var ekkoer af den stemning, der prægede deres newsfeed. ${ }^{\mathrm{x}}$ Spørger man Mark Zuckerberg og hans nærmeste medarbejdere, hvad i alverden formålet med den slags undersøgelser er, lyder svaret noget i retning af følgende: Facebook ønsker at personalisere og individualisere sine tjenesteydelser, for brugernes skyld. Holder du f.eks. af sorbet-is, er der jo ingen grund til, at du igen og igen skal præsenteres for tilbud om flødeis. Går dine politiske holdninger i samme retning som Dansk Folkepartis, vil vi gerne spare dig for ophidselsen ved at se nyheder, som er guf for Det Radikale Venstres udlændingepolitik. Møder man et menneske - og det kan jo ske - der opfatter det som en behagelighed, at Facebooks algoritmer således er i stand til at træffe valg på ens vegne, må man bare konstatere, at den pågældende ville egne sig fortræffeligt som undersåt i det hedengangne DDR eller et andet af kommunismens totalitære vasal-samfund. Han eller hun overlader sin personlige skæbne til et velmenende system, akkurat som Václav Havels berømte grønthandler, der for bekvemmeligheden skyld anbragte skiltet "længe leve proletariatets diktatur" i sit butiksvindue. Selv har jeg for nylig truffet en studerende, der erklærede sig overbevist om, at en algoritmisk baseret App ville være bedre til at vælge den helt rette kæreste for ham, end hans egne, hormonledsagede iagttagelser.

\section{4 .}

Det lyder måske som historiens afslutning, men nej: Facebook Inc. har endnu et trick i ærmet. Et trick, der bare gør ligheden med det kommunistiske Central- og Østeuropa endnu mere slående. Facebook vil nemlig også afgøre, hvilke informationer, der overhovedet skal tilgå os! Som med alt, hvad Zuckerberg foretager sig, er hensigten højstemt ædel. ${ }^{x i}$ Vi ved jo alle, hvordan moderniteten er et overfyldt og støjplaget rum. Det gælder ikke mindst den elektroniske 
offentlighed. Nyheder og nyhedsanalyser kommer uafbrudt væltende over hundredvis af globale kanaler og fra enhver kant. Hvordan skal vi overhovedet kunne sortere i al den information? - Jamen, hvad ville være bedre end at se efter, hvad vore venner anbefaler og lade være med at ulejlige os med alt det, de filtrerer fra? Lige siden studietiden har Zuckerberg svømmet i vennekliker.xii "Facebook" er den amerikanske benævnelse for det, vi i Danmark kalder en "blå bog", som dimitterende studenterklasser har for vane at udgive, med billeder og tekstomtale af hver enkelt elev. Hvis nu det lykkes at lade vores venner sortere nyhederne for os, så har vi i realiteten frembragt en "personaliseret avis", lyder ræsonnementet.xiii Det er virksomheden Facebook Inc.'s overordnede ambition: at blive verdens altdominerende avis - hele verdens Avis No. 1 .

Det er et stort ansvar at påtage sig: at sørge for, at alle mennesker i verden modtager de mest relevante nyheder og ikke belemres med de ligegyldige og de falske. I det 20.århundrede var den opgave fordelt på et større antal ansvarshavende redaktører ved førende dagblade og public service-stationer: nyhedsredaktørerne på BBC, The New York Times, The Washington Post, Le Monde, The Times, El País, Frankfurter Allgemeine Zeitung og en lang række andre dagblade og nyhedsmedier af høj troværdighed. Demokratiets portvagter - gatekeepers - kaldtes de i den engelsksprogede verden. Mark Zuckerbergs vovestykke er at disrupte disse mange betroede stillinger og selv overtage dem alle på én gang.

Projektet er ikke blot en afspejling af studenten/ynglingen/halv-nørden's puerile hovmod. Det er også en pest over demokratiet. Men "herregud", som omkvædet lyder, "vi giver så lidt, og vi får så meget til gengæld".

Meget længe har der været tavshed om Facebooks newsfeed. Først efter det amerikanske præsidentvalg i november 2016, begyndte man at høre anklager om Facebooks mulige bidrag til vildledende informering af vælgerne. Og den 27. april 2017 udsendte koncernen selv et 12 sider langt "white paper", som grundlæggende giver mange af disse anklager medhold. xiv Det drejer sig blandt andet om såkaldt "falske forstærkere". De kan enten kan komme fra robotter på de sociale medier, kaldet "sociale bots" - altså automatiserede tweets og lignende - eller fra målrettede interventioner, hvor suspekte aktører hacker indhold fra websites og diverse servere og derefter gør dette indhold tilgængeligt på nyoprettede websider under falske navne.

Disse erkendelser ledte imidlertid ikke koncernen til at konkludere, at man nok har satset for højt i bestræbelsen på at bliver verdens førende - og i sidste ende eneste - nyhedsavis. Tværtimod indeholder bemeldte "white paper" en række tilkendegivelser om, at Facebook herefter vil opgradere sikkerheden. Og i sin traditionelle nytårserklæring (4. januar 2018) erklærer 
Zuckerberg det nu som sin hensigt, at Facebook skal "fixes" i årets løb.xv Hvad det betyder, er, at Facebooks algoritme - en programkode på mere end 50 millioner linjer - vil blive ændret her og der.

Begyndelsen har dog ikke været særlig køn. Den 19. oktober 2017 ændrede man som et forsøg FB-brugernes newsfeed i seks udvalgte lande, repræsenterende omkring $1 \%$ af klodens befolkning: Guatemala, Bolivia, Sri Lanka, Cambodia, Slovakiet og Serbien. I disse lande fjernede Facebook fra den ene dag til den anden de former for newsfeed, der kom fra offentlige medievirksomheder, således at brugerne kun modtog opdateringer i form af poster fra venner, plus betalt indhold (annoncer).

For nogle medier var resultatet en katastrofe. I Guatemala, et land med meget vanskelige vilkår for uafhængig journalistik, mistede netmediet Soy502 i løbet af et døgn 66\% af sine besøgende.xvi I Slovakiet viste undersøgelser, at "engageret læsning" (læsning fulgt op med videre anbefalinger etc.) af de medier, der har oprettet Facebook-sider, faldt med 60\% i løbet af det samme døgn. Fra demokratiets perspektiv er det selvfølgelig uhyggeligt, at Facebook Inc. på denne lemfældige måde eksperimenterer med store borgergrupper og den politisk betydningsfulde information, der tilgår dem. Endnu mere uhyggeligt er det måske, at så mange mennesker så hurtigt er blevet "politisk afhængige" af en enkelt global koncern i San Francisco.

Senest har Zuckerberg nu meddelt, at en ændring i tilsvarende retning vil blive implementeret globalt. ${ }^{\text {vii }}$ I stedet for at lade FB-sidernes newsfeed kuratere af koncernens hidtidige algoritme, vil Facebook foranstalte "brugerundersøgelser" om, hvilke nyhedskilder, FB-brugerne anser for at være mest troværdige. Vi kunne spørge en række medieeksperter, vi kunne også spørge os selv, men vi vil hellere spørge jer brugere, erklærede Zuckerberg - stadig trofast mod sin oprindelige alumne-ideologi, men også bekvemt ansvarsfralæggende.

\section{5.}

Det seneste års tid er en del forskellig kritik af Facebook begyndt at dukke op i offentligheden. Omsider, fristes til at tilføje. Langt størsteparten af kritikken drejer sig om Facebooks skadelige indvirkning på børn og unges liv - også en meget vigtig dimension, men ikke den, vi har haft fokus på her.

I maj 2017 afslørede en læk i Australien, at virksomhedens ledelse har demonstreret overfor potentielle kunder (annoncører), hvordan man er i stand til at aflæse, når teenagere føler sig usikre, "værdiløse", og har behov for at få masseret deres selvtillid. Facebook Inc. kan registrere de unge brugeres opdateringer og billeder i realtid og på det grundlag afgøre, om den pågældende 
lige nu føler sig 'stresset', 'ængstelig', 'dum', 'ubrugelig' og mere til.xviii Man kan uden videre antage, at firmaets egen teknologi bidrager en hel del til netop det: at de unge føler sig værdiløse og ubrugelige. For, som den tidligere ledelsesguru Umair Hague rigtigt konstaterer: "Facebook's mægtigste våben er den endeløse sammenligning af os selv med andre". xix Ikke underligt, at koncernen efterfølgende har søgt at mørklægge sagen.

Kronikker, essays og bøger om unges afhængighed og misbrug af de sociale medier, og om Facebooks evne til hele tiden at fange vores opmærksomhed og distrahere os, begynder nu at udkomme i en lind strøm. Det er et skridt i den rigtige retning. Men det er også et tema, der overlader det til hver enkelt Facebook-bruger at afgøre med sig selv, om han eller hun kan styre sit forbrug, og om man som forældre kan regulere sine børns forbrug. (Det mener de fleste sjovt nok at kunne.)

Den kritik, der handler om Facebooks erodering af hele samfundets demokratiske kultur, er til gengæld meget mere besværlig. For den giver os - som en ægte etisk fordring - ikke kun ansvaret for at styre os selv og vores børn, med vores eget og vore børns tarv for øje. Den giver os et medansvar for hele det samfundsmæssige fællesskab.

Så med mindre du er kommunist, putinist, erdoganist eller på anden måde totalitært sindet, kan du ikke være bekendt at opretholde en Facebook-profil. Luk nu ned!

Klavs Birkholm er direktor i tanketanken TeknoEtik.

\footnotetext{
i Ivan Krastev, ”Can Democracy exist without trust?”, TED-Talk 2012.

ii ”Ex-Stasi boss green with envy over NSA's domestic spy powers", Cl net June 28 2013. Se også interviewet med McClatchy Washington Bureau 26.06.2013.

iii Václav Havel, "De magtesløses magt", (side 24-109) i De Magtesløses Magt (Essays udvalgt og oversat af Peter Bugge), Gyldendal 1991. - Denne tekst burde være obligatorisk læsning for enhver dansk skoleelev i nutiden.

iv Bruce Schneier, Data and Goliath: The Hidden Battles to Collect Your Data and Control Your World. 2015: W.W. Norton. - - Shoshana Zuboff, "Big other: surveillance capitalism and the prospects of an information civilization". Journal of Information Technology. 2015, vol. 30. pp. 75-89.

v Hannah Arendt, The Human Condition. 1958. London: The University of Chicago Press.

vi Se også: Klavs Birkholm, "Den Anden Oplysningstid", KlavsBirkholm.dk 2.januar 2017.

vii Joseph Turow, Michael Hennesy \& Nora Draper, THE TRADEOFF FALLACY: How Marketers Are Misrepresenting American Consumers And Opening Them Up to Exploitation. A Report from the Annenberg School for Communication. June 2015.
} 
viii A "majority of Americans are resigned to giving up their data - and that is why many appear to be engaging in trade-offs. Resignation occurs when a person believes an undesirable outcome is inevitable and feels powerless to stop it. Rather than feeling able to make choices, Americans believe it is futile to manage what companies can learn about them. Our study reveals that more than half do not want to lose control over their information but also believe this loss of control has already happened." Ibid., p.3.

ix Tom Simonite, "What Facebook Knows", MIT Technology Review, 13.06.2012

x Adam D. I. Kramera, Jamie E. Guillory, Jeffrey T. Hancock, "Experimental evidence of massive-scale emotional contagion through social networks", Proceedings of the National Academy of Sciences vol. 111 no. 24. 20014: pp. 8788-8790 (DOI: 10.1073/pnas.1320040111). - "We show, via a massive ( $\mathrm{N}=689,003)$ experiment on Facebook, that emotional states can be transferred to others via emotional contagion, leading people to experience the same emotions without their awareness. We provide experimental evidence that emotional contagion occurs without direct interaction between people (exposure to a friend expressing an emotion is sufficient), and in the complete absence of nonverbal cues."

xi Det var som bekendt også tilfældet med de kommunistiske "folkerepublikker".

xii Franklin Foer, World Without Mind. London 2017: Jonathan Cape. pp. 57-61 et passim.

xiii Alexandra Chang, "Facebook Reveals a 'New Look for Newsfeed"' (Liveblog), Wired 07.03.2013. Se også samme forfatter: "Facebook promises a 'New Look for Newsfeed"', Wired, 01.03.2013.

xiv Jen Weedon, William Nuland \& Alex Stamos, Information Operations and Facebook. April 27, 2017.

Version 1.0

xv "My personal challenge for 2018 is to focus on fixing these important issues. We won't prevent all mistakes or abuse, but we currently make too many errors enforcing our policies and preventing misuse of our tools. If we're successful this year then we'll end 2018 on a much better trajectory." (Mark Zuckerberg, Facebook-post 4.januar 2018)

xvi Alex Hern, "'Downright Orwellian': journalists decry Facebook experiment's impact on democracy", The Guardian, 25.10.2017.

xvii I første omgang dog som et forsøg kun i USA. Dave Lee, "Facebook to use surveys to boost 'trustworthy' news", BBC News, 19.01.2018.

xviii Sam Levin, "Facebook told advertisers it can identify teens feeling 'insecure' and 'worthless':

Leaked documents said to describe how the social network shares psychological insights on young people with advertisers", The Guardian, 01.05.2017.

xix Og: "Facebook makes us miserable by inducing us to constantly engage in me versus you interactions". Umair Hague, "Can Facebook Redeem Itself" (Part 1 \& Part 2), Eudaimonia \& Co, 16.01 og 17.01.2018. 